\title{
LIVING TOGETHER WITH LGBT PEOPLE IN INDONESIA
}

\author{
Subehan Khalik \\ Fakultas Syariah dan Hukum Universitas Islam Negeri Alauddin Makassar \\ subehan.khalik@uin-alauddin.ac.id
}

\begin{abstract}
Indonesia as the country with the most Muslim population in the world faced the challenge of placing LGBT actors in the state-citizen structure. The teachings of Islam expressly reject the LGBT Act, while the State is obliged to present in advocating the rights of LGBT actors for the reasons for enforcing human rights. In the meantime, LGBT actors still have no proper treatment and are vulnerable to discrimination, so the LGBT community seems to have no right to return to repentance. Islam as a religion that has the value of humanity, on the one hand, opened a wide path for the perpetrator to return to the way of God and the other side affirmed that LGBT behavior is the thing forbidden. This research is a juridical-normative study with a theological-normative approach (Syar'i), consisting of research on principles, systematics, and the synchronization of laws using Islamic law to approach objects. The research aims to formulate a new approach to LGBT actors to avoid discrimination and rediscover the path of repentance. The study found that structured efforts to approach LGBT actors will open up opportunities for them to repent and to those who wish to remain standing on their status, can be protected by regulatory Indonesian law has ratified UDHR and partial UDHR (Cairo Declaration).
\end{abstract}

Keywords:

LGBT actors; Advocacy; Human rights; Repentance; Discrimination

\begin{abstract}
Abstrak
Sebagai negara dengan populasi Muslim terbanyak di dunia, Indonesia menghadapi tantangan untuk menempatkan aktor LGBT dalam struktur warga negara. Ajaran Islam secara tegas menolak LGBT, sementara Negara berkewajiban untuk hadir dalam mengadvokasi hak-hak para pelaku LGBT dengan alasan untuk menegakkan hak asasi manusia. Sementara itu, para pelaku LGBT masih tidak memiliki perlakuan yang layak dan rentan terhadap diskriminasi, sehingga komunitas LGBT tampaknya tidak memiliki hak untuk kembali ke pertobatan. Islam sebagai agama yang memiliki
\end{abstract}


nilai kemanusiaan, di satu sisi membuka jalan lebar bagi pelaku untuk kembali ke jalan Tuhan dan di pihak lain menegaskan bahwa perilaku LGBT adalah hal yang dilarang. Penelitian ini adalah penelitian Yuridis-Normatif dengan pendekatan teologi-normatif (syar'i), dimana terdiri dari penelitian tentang prinsip, sistematika, dan sinkronisasi hukum dengan menggunakan hukum Islam untuk mendekati objek. Penelitian ini bertujuan untuk merumuskan format pendekatan baru terhadap actor LGBT agar dapat terhindar dari diskriminasi dan menemukan kembali jalan pertobatan. Penelitian ini menemukan bahwa upaya terstruktur dalam melakukan pendekatan kepada actor LGBT akan membuka peluang bagi mereka untuk melakukan pertobatan dan terhadap mereka yang berkeinginan tetap berdiri di atas status mereka, dapat dilindungi oleh regulasi hukum sebab Indonesia telah meratifikasi UDHR dan Parsial UDHR (Deklarasi Kairo).

Kata Kunci:

Aktor LGBT; Advokasi; Hak asasi Manusia; Tobat; Diskriminasi

\section{A. INTRODUCTION}

7 he Liputan6.com coverage on May 26, 2017 reported the four LGBT cases that are the world's highlights. ${ }^{1}$ Such cases were; The gay party in Kelapa Gading was caught on May 25, 2017; The sentence of whip Gay couple held on 23 May 2017; Gay wedding in Bali in September 2015 and Surabaya Gay Party in Hotel Oval Surabaya Room on 30 April 2017. This fact revealed that the position of Indonesia in LGBT terms is very distinctive in the eyes of the world because this major event can be unnoticed by the public and rise when the authorities have announced their arrest report.

Lesbian, Gay, Bisexual, Transgender (hereinafter called LGBT) is a social phenomenon that has direct correlation with religion. This act in the view of religion is a disgrace and a great sin as is what the Prophet Lut had done. ${ }^{2}$ But on the surface appears in a few circles, the people have expressed themselves as perpetrators of this act and did not worry about the public perception towards their deeds. This behavior started since 1970 and became a new phenomenon in the 2001 as the Netherlands legalizes same-sex marriage as legal. ${ }^{3}$

\footnotetext{
${ }^{1}$ https://www.liputan6.com/global/read/2963642/4-kasus-lgbt-di-indonesia-yang-disorot-dunia

${ }^{2}$ QS. al-Syu'arā/26 : 165-166;

3 Stephen T. Russell dan Jessica N. Fish, "Mental Health in Lesbian, Gay, Bisexual, and Transgender (LGBT) Youth," Annual Review of Clinical Psychology (2016). p. 465-466.
} 
A study in the United States found that LGBT behavior is vulnerable to bring psychological influences to the culprit to tend to commit suicide. However, the report then affirmed that the trigger factor of suicide attempts by LGBT actors due to discrimination by people around them. ${ }^{4}$ In other parts, it is also found that LGBT actors with kids are prone to problems in raising their children than families of different types of couples. In 2005 only one state in America to legalize similar partner relationship and year 2015 or ten years thereafter, the condition has reversed in the presence of laws that legalize similar partner relations in the states across U.S. ${ }^{5}$

Unlike Indonesia, LGBT existence occupies a gray position because the lawstill does not give clarity to the perpetrators. Supardji Ahmad stated there was a legal vacuum in Indonesia for lesbian, gay, bisexual and transgender people. The void of law impresses LGBT activities is not legal deeds. This statement commented on the verdict of the Constitutional Court (MK) of judicial review lawsuit submitted by IPB Euis Sunarti's professor of chapters 284, 285 and 292 of the CRIMINAL code. The Mahkamah Konstitusinal's refusal to Euis Sunarti's lawsuit gave a new chapter on LBGT development in Indonesia. ${ }^{6}$

How the fate of LGBT actors in Indonesia will be in the future, this article will critically review about "how LGBT existence in Islamic and positive laws in Indonesia with sub-problems: How the historical background of LGBT in Indonesia; How to view Islamic law on LGBT actors and how LGBT existence in Indonesia's positive law.

This research aims to explore LGBT in Indonesian law regulation and to find a new format for socializing in the middle of the Indonesian Muslim majority group. The process of achieving that goal is using normative juridical approaches; Shar'i and Sociology of law. To draw the two opposite poles to the LGBT people is tricky, one side they remain protected by their fundamental rights while it needs to find the way to return them to basic behavior in religious teachings.

\section{B. THE HISTORY OF LGBT IN INDONESIA}

It cannot be found in academic writings regarding the history and development of LGBT in Indonesia, but it is believed that the identity of new homosexuality emerged in major cities in Indonesia in the early decades of the 20th century. The alleged LGBT emergence was reinforced with an article on LGBT history in Indonesia, reported by Republika.co.id in a post titled "The LGBT Journey

\footnotetext{
${ }^{4}$ Dejun Su et al., "Mental Health Disparities Within the LGBT Population: A Comparison Between Transgender and Nontransgender Individuals," Transgender Health, 1.1 (2016), p. 12-20 <https://doi.org/ 10.1089/trgh.2015.0001>.

5 Gary J Gates, "Marriage and Family: LGBT Individuals and Same-Sex Couples," The Future of Children 25, no. 02 (2015): 67-87.

${ }^{6}$ https://nasional.tempo.co/read/1044655/pakar-hukum-ada-kekosongan-hukum-tentang-lgbt-di-indonesia
} 
in Indonesia".7 This article explains that LGBT in Indonesia began to be tracked in 1960s when the term Sentul and Kantil were spread which now has changed to the title Buci and Femme. ${ }^{8}$ It was also mentioned that the organization and advocacy of LGBT have stood a long time, it can be observed on the proliferation of organizations such as; HIWAD (set of Wadam Djakarta), Wadam, female Adam and Wimad. This last organization was subsequently protested by the Indonesian Ulama Council (MUI).

In 1982 the perpetrators of homosexuality established an institution called LAMBDA Indonesia. In four years (1986), the Indonesian Lesbian group also established a unity group called PERLESIN (Indonesian Lesbian Association), a lesbian and gay archipelago Working group. In the range of 1990, similar organizations began to wide-spread in Indonesia. the LGBT movements taking an opportunity by hiding under the issue of emancipation. ${ }^{9}$ The dramatic change in political temperatures in 1988, has opened the opportunity for this movement to grow. It was recorded that in 1988 the Indonesian Women's Congress held an event in December and formally included the representatives of the lesbian, bisexual women and transgender men (LBT) in Congress. The Indonesian Women's Coalition for Justice and Democracy (KPI) is officially affirmed to include the XV sector which is those in the category (LGBT). ${ }^{10}$

LGBT movement in Indonesia can be seen from the results of the report of the Indonesian LGBT National dialogue held in Bali on 13-14 June 2013 stating that until the end of 2013 two major LGBT networks in Indonesia had 119 Organization's network. The distribution of organizations includes 28 out of 34 provinces in Indonesia. ${ }^{11}$ The movement was funded by international donor agencies such as USAID, AusAID, UNAID and UNFPA and the biggest funding was sourced from a Dutch organization named Hivos and sometimes also sourced from Dutch government funds-Ford Foundation. ${ }^{12}$ The donor groups and the drive of the LGBT campaign were instrumental in the dissemination of information, movements and LGBT organizations in Indonesia. This movement aims to minimize the negative

\footnotetext{
7 http://www.republika.co.id/berita/jurnalisme-warga/wacana/16/01/28/o1n41d336-menelisik-perjalananlgbt-di-indonesia

${ }^{8}$ http://www.republika.co.id/berita/jurnalisme-warga/wacana/16/01/28/o1n41d336-menelisik-perjalananlgbt-di-indonesia

9 http://www.republika.co.id/berita/jurnalisme-warga/wacana/16/01/28/o1n41d336-menelisik-perjalananlgbt-di-indonesia

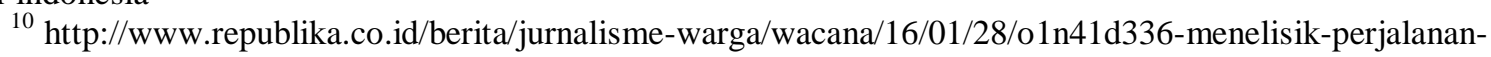
lgbt-di-indonesia

${ }^{11}$ Khanis Suvianita Dédé Oetomo, Hidup Sebagai LGBT di Asia, Laporan LGBT Nasional Indonesia, Cet.I (Bali: UNDP, 2013), p.3-6

${ }^{12} \mathrm{http}: / / w w w . r e p u b l i k a . c o . i d /$ berita/jurnalisme-warga/wacana/17/12/22/p1cv94396-lgbt-konspirasiglobal-acaman-keluarga-indonesia
} 
treatment of LGBT by the people and to campaign for the protection of LGBT in Indonesia from discrimination. ${ }^{13}$

The campaign of the LGBT movement and international advocacy did not make LGBT being accepted by Indonesians. Wahid Foundation was reported on 29 January 2018, LGBT is the most hated by Indonesians proved by $17.8 \%$ respondents, just under the communist issues which stood that the similar hatred may increase compared to 2016 which shows that $16.7 \%$ of Indonesians hate LGBT and $26.1 \%$ of the Communist hater. ${ }^{14}$ Suppression and hatred of LBGT perpetrators also occur in Turkey. It undertook the declaration of the Society for the Sexual Education of Medicine and Research (CETAD) and the Turkish Psychiatry association that heterosexual, homosexuals and bisexuals were one of sexual orientation. This statement did not stop the behavior of discrimination against LGBT actors and caused them to abandon their homes and the environment that raised them. The research also reported that of the 30 respondents they interviewed, it was found that LGBT actors tend to get social problems not only in their native regions but also in their new places. ${ }^{15}$

What happened in Indonesia as well as Turkey became a strong foundation suggesting that LGBT faces strong opposition from the Muslim community. Of course, such harmful behavior is without foundation, so it is interesting to conduct a study of the evidence of Islamic law on LGBT.

\section{ISLAMIC LEGAL VIEWS ON LGBT}

The Indonesian Ulama Council (MUI) has been issued a fatwa about LGBT in the MUI Fatwa Number 57 2014. The Fatwa was issued on December 31, 2014, contains 11 legal provisions on LGBT acts and 4 recommendations. ${ }^{16}$ It is interesting to note that MUI expressly elaborated on the attitude statement on LGBT behavior and recommends the Government to make the legislation of the LGBT legality in Indonesia. The awakened rules are intended to be a deterrent giver for perpetrators and become a deterrent element for prospective perpetrators.

LGBT is a deviant social behavior that has been existed for ages and naturally is very old. This behavior has been implemented by the people of the Prophet Lut as enshrined in the QS al-syu'arā/26:165-166 as follows:

${ }^{13}$ Ilan H. Meyer, "The elusive promise of LGBT equality," American Journal of Public Health 106, no. 8 (2016): 1356-1358.

$14 \mathrm{https} / / /$ nasional.sindonews.com/read/1277651/15/komunis-dan-lgbt-menjadi-kelompok-yang-palingtak-disukai-di-indonesia-1517218449

15 Zümrüt Biçmen dan Zafer Bekiroğulları, "Social Problems of LGBT People in Turkey," Procedia Social and Behavioral Sciences, 113 (2014), p. 224-233 <https://doi.org/10.1016/j.sbspro. 2014.01.029>.

16 Lebih lanjut lihat Fatwa MUI tentang Lesbian, Gay, Sodomi dan Pencabulan dalam https://lampung.kemenag.go.id/files/lampung/file/file/MUI/xdob1460683589.pdf 


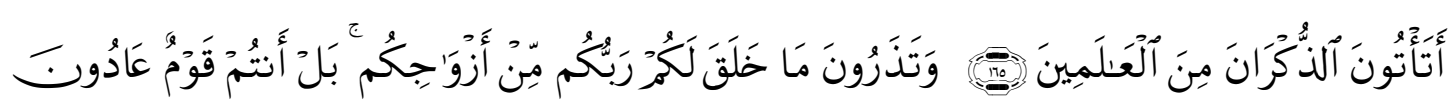

Reciters:

Why do you approach the kind of man among men, and you leave wives made by your Lord for you, you are the ones who exceed the "limit". ${ }^{17}$

God's Word on QS al-a'rāf/7:33 as follows:

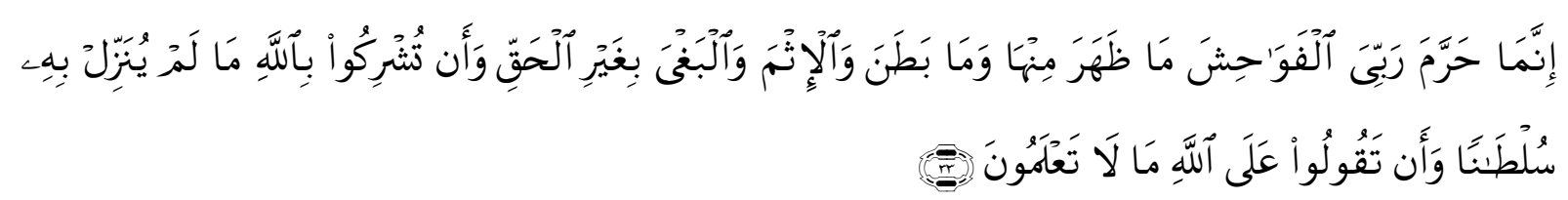

Reciters:

Say: "My lord just forbidden the vile deeds, both the visible and the hidden, and the deeds of sin, violating human rights without the right reason, (Prohibition) to associate God with something God did not degrade and (Prohibition) invent against God what you do not know. ${ }^{18}$

LGBT phenomena of the Prophet Luṭ enshrined in QS al-a'rāf/7:80-81:

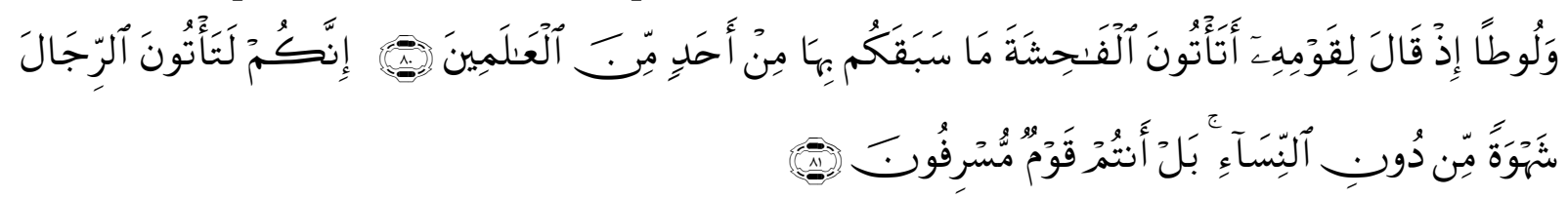

Reciters:

And (we have also sent) Lut (to his people). (remember) when he said to them: "Why are you doing the Fāhisyah deeds that no one else (in this world) has ever done before you? ". ${ }^{19}$

LGBT in the Prophet's Hadith is also mentioned in the category Liwāt which is threatened with the following penalty:

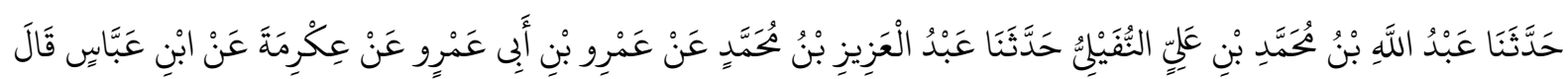

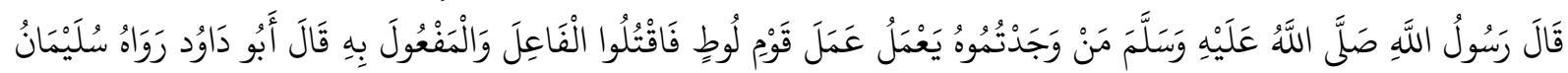

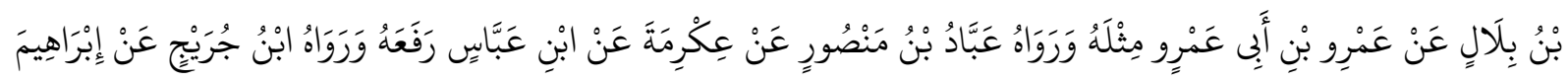

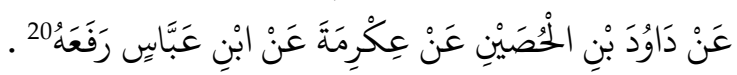

Means:

Narrated by Abdullāh bin Muhammad bin' Ali Al-Nufailī ; 'Abd Al-Azīz bin Muhammad from ' Amru bin Abū Amru from Ikrimah from Ibn Abbās; he said, "Rasulullah Sallalleahu' alaihi wasallam saying: "Who you find is doing the Lut, then slay; The perpetrators and their objects. "Abū Dāwud said," Sulaimān bin Bilāl tells him from' Amru bin Abū' Amru like

\footnotetext{
${ }^{17}$ Kementrian Agama RI. Alquran dan Terjemahnya (Semarang: Toha Putra Semarang, 2014), p. 585

${ }^{18}$ Kementrian Agama RI. Alquran dan Terjemahnya (Semarang: Toha Putra Semarang, 2014), p. 585

${ }^{19}$ Kementrian Agama RI. Alquran dn Terjemahnya, p. 234.

${ }^{20}$ Imām Abū Dāwūd, Sunan Abī Dāwūd, Juz VII (Beirut: Dār al-Kutub al-'Ilmiyyah, t.th), p. 157.
} 
that hadith. And Abbād ibn Manșūr was narrated from Ikrimah, from Ibn 'Abbās, and he reproved him. Ibn Juraij narrated it from Ibrāhim, from Dāwūd ibn al-Hușain, from Ikrimah, from Ibn Abbās, and he made it marfu'.

The other side of LGBT existence is also being contrary to the spirit of maslahat in Islamic law. The maslahat which became the point of the enactment of the logical evidence advocated protection against descent. The human prevention from harmful things to his life is one part of the Maqașịid al-Syarī'ah (The purpose of Revelation Syariat), which is the creation of welfare for man in two realms (the World and the Hereafter). ${ }^{21}$ Human welfare to avoid damage is a major milestone of the aims of Syari'at. People from the beginning have been endowed with reason to manage all sorts of information sourced from revelation. ${ }^{22}$

\section{LGBT FROM LEGAL PERSPECTIVE IN INDONESIA}

A recent study in Jakarta conducted by Gadis Arivia and Dewi Ganis symbolizes that there are four factors that make LGBT behavior discriminatory; First, that most people believe that a fellow relationship is something forbidden by religion; Secondly, many people believe that LGBT behavior is an inevitable lifestyle and the culprit is considered to be a foolish person and therefore, this behavior needs no protection of rights; Thirdly, since LGBT is a glamorous lifestyle, it is not found that the perpetrators come from the poor and the fourth, LGBT actors do not want their behavior to be publicly known so they tend to close themselves and keep the tendency of their sexuality. ${ }^{23}$

LGBT is an important part of Universal's Human Rights (hereinafter referred to as HAM Universal in the Universal Declaration of Human Right and sometimes contrary to local culture born by the religious Understanding (hereinafter referred to as Partial human rights). The conflict between Universal HUMAN rights and partial human rights gave rise to conflicts of law and to distort LGBT in basic legal aspects. This fact is a necessity to remember that two poles of interest will be pitted when discussing Universal's rights. For Abdullahi Ahmad An-Na'im the conflict between Universal HUMAN rights and partial human rights will continue to occur and each of them will produce partial human rights sourced from norms of local beliefs and culture. ${ }^{24}$ In this context, Islamic law represents partial human rights firmly rejecting

\footnotetext{
${ }^{21}$ Abū Isḥaq al-Syāțib̄̄, al-Muwāfaqāt fĩ Ușūl al-Syarī'ah Juz II (Beirūt: Dār al-Ma’rifah, 1997), p. 324.

${ }^{22}$ Subehan Khalik, "NAJAMUDDIN AL-ṬŪFĪY DAN KONSEP MAȘLAḤAT," Aldaulah: Jurnal Hukum Pidana dan Ketatanegaraan, 5.1 (2016), 109-118<https://doi.org/10.24252/ad.v5i1. 1444>.

${ }^{23}$ Gadis Arivia \& Abby Gina, QUEERING INDONESIA : When the State is Absent : A Study Og LGBT Community in Jakarta, ed. oleh Lea Šimek (Jakarta: YJP Press, 2016), p. 4-12 <www.jurnalperempuan. org/indonesian-feminist-journal.html>.

${ }^{24}$ Abdullahi Ahmed An Na'im, Toward an Islamic reformation: Civil liberties, Human Rights, and International Law, 5 ed. (New York: Syracuse University Press, 1996). p. 127.
} 
LGBT existence and making this act a forbidden deed and regarded as a heinous deed.

The dichotomy of Basic Law that encircles LGBT gave birth to fundamental doubts in establishing the basic laws about the prohibition in Indonesia, although Indonesia does not fully acknowledge Universal human rights but as well does not fully accept it considering Indonesia has a different perception about Universal human rights. ${ }^{25}$ This expression is very basic because Indonesia is a country that is a state of partial human Rights in the Cairo Declaration in 1990. The essence of the Cairo Declaration is the acknowledgment of human rights universally attributed to the values sourced from Islamic teachings therefore in certain cases there will be gaps between the two, especially when talking about Religious displacement and prohibition for Muslim women to marry non-Muslim men. ${ }^{26}$ The dichotomy in Universal and partial human rights have influenced the Indonesian government's stance on establishing basic LGBT laws in Indonesia.

Efforts have been made to minimize the pace of LGBT growth in Indonesia, but LGBT behavior continue growing. Even in Aceh efforts to minimize LGBT actors had done with a preventive approach through socialization to the community. According to Putri Keumala, the local government through Wilayatul Hisba has made the utmost effort to stem the rate of LGBT. But it indicated that LGBT in Aceh is still above 500 people. Despite the punishment of whipping the perpetrators, this sentence does not necessarily diminish LGBT behavior. ${ }^{27}$

The draft of the Criminal Code of Law (RKUHP) has incorporated LGBT in criminal acts as expressed by Bambang Soetsatyo in article 495 of RKUHP, it has been agreed that LGBT categories into criminal acts of fellow obscene deeds and the country is obliged to punish it. In this case, ${ }^{28}$ the DPR has agreed with the MUI in terms of LGBT, but they are then different opinions in terms of the age limit which is under as the basis of criminal imposition on the RKUHP. MUI has the view that the age limit should not be in the draft RKHUP considering that LGBT is as well exist in the age of adults over 18 years. ${ }^{29}$

A dualism attitude between MUI and the government apparently will not bring a meaningful impact on LGBT actors in Indonesia. The attitude of MUI which refused to be understood as an attempt to place religious teachings and become a compass for people's life in one side. On the other side the state must defending the rights of its people. For those who have been exposed to LGBT behavior, the MUI

25 St. Harum Pudjiarto. Hak Asasi Manusia di Indonesia: Suatu Tinjauan Filosofis Berdasarkan Pancasila dan Permasalahannya dalam Hukum Pidana (Yogyakarta: Universitas Atma Jaya, 1993), p. 73

${ }^{26}$ Muhammad Hafiz, "Dinamika Hukum Dan Hak Asasi Manusia Di Negara-Negara Muslim," Al-Ahkam, 23.2 (2013), p. 201-24<https://doi.org/10.21580/ahkam.2013.23.2.23>.

${ }^{27}$ Putri Kemala, "Peran Wilayatul Hisbah Dalam Mencegah Lesbian, Gay, Biseksual Dan Transgender (Lgbt) Di Banda Aceh,” Al-Idarah: Jurnal Manajemen dan Administrasi Islam 1, no. 2 (2017): 261.

${ }_{28} \mathrm{https} / / /$ nasional.tempo.co/read/1057953/dpr-dan-mui-sepakat-lgbt-dipidana-dalam-rkuhp

${ }^{29} \mathrm{https} / / /$ nasional.tempo.co/read/1057953/dpr-dan-mui-sepakat-lgbt-dipidana-dalam-rkuhp 
and the State must present advocacy for LGBT actors while seeking their return to the right path. That is why it is very reasonable to say that the LGBT actors are ordinary people who need a helping hand to be invited to return to God's way. They are not anyone enemies, or beings discriminated and marginalized in a community.

\section{E. CONCLUSION}

The LGBT discussion first appeared in the period of 1960s The advocacy movement against LGBT began in 1982 when homosexual actors were being called LAMBDA and followed in 1986 by the Indonesian Dyke also established an organization called PERLESIN. In 2013 about 119 LGBT Organization were established and they were divided into two large groups that comprise 28 province of 34 Province in Indonesia.

LGBT Conduct in Islamic law belongs to the category of heinous deeds and the threat of punishment is equated with the punishment of adultery. This act is a phenomenon of society that never happened to society before the people of the Prophet Lut.Rasulullah saw. threated LGBT (homosexuality) to be both killed. The threat of punishment promised for LGBT in this context will contradict with the recognition of human rights as found in the Universal Declaration of Human Rights.

Indonesia as one of the countries ratified the Cairo Declaration in a manner that adheres to the human rights sect in a partial context in one handshould determining the punishment for LGBT based on the basic doctrines and norms of the Indonesian legal community. On the other hand, the Indonesian community adheres to Islam as the majority religion thus the values in Islamic teachings will occupy the existing legal spaces including when talking about LGBT. The legal logic is represented when the DPR RI has entered LGBT in the RKUHP whose contents include LGBT as an obscene act and the perpetrators are threatened by criminal penalties, but this applies to actors who are under 18 years old. LGBT actors in Indonesia should have protection so that they avoid discrimination while seeking a way to invite them to return to God's way. MUI and the government should hand in hand to develop regulations on LGBT behavior to make it easier for perpetrators to find the right way in their lives.

\section{Bibliography}

Abū Dāwūd, Sunan Abī Dāwūud, Juz VII Beirut: Dār al-Kutub al-‘Ilmiyyah, t.th

Biçmen, Zümrüt, dan Zafer Bekiroğulları. "Social Problems of LGBT People in Turkey." Procedia - Social and Behavioral Sciences 113 (2014): 224-233.

Dédé Oetomo, Khanis Suvianita. Hidup Sebagai LGBT di Asia. Laporan LGBT Nasional Indonesia. Cet.I. Bali: UNDP, 2013. 
Gadis Arivia \& Abby Gina. QUEERING INDONESIA: When the State is Absent: A Study Og LGBT Community in Jakarta. Diedit oleh Lea Šimek. Vol. 4. Jakarta: YJP Press, 2016. www.jurnalperempuan.org/indonesian-feminist-journal.html.

Gates, Gary J. "Marriage and family: LGBT individuals and same-sex couples." The Future of Children (2015): 67-87.

Hafiz, Muhammad. “Dinamika Hukum Dan Hak Asasi Manusia Di Negara-Negara Muslim." Al-Ahkam 23, no. 2 (2013): 201-224.

Kemala, Putri. "Peran Wilayatul Hisbah Dalam Mencegah Lesbian, Gay, Biseksual Dan Transgender (Lgbt) Di Banda Aceh." Al-Idarah: Jurnal Manajemen dan Administrasi Islam 1, no. 2 (2017): 261.

Khalik, Subehan. "NAJAMUDDIN AL-ṬŪF̄Y DAN KONSEP MAȘLAḤAT." Aldaulah: Jurnal Hukum Pidana dan Ketatanegaraan 5, no. 1 (2016): 109-118. http://journal.uin-alauddin.ac.id/index.php/al_daulah/article/view/1444/1396.

Meyer, Ilan H. "The elusive promise of LGBT equality." American Journal of Public Health 106, no. 8 (2016): 1356-1358.

Na'im, Abdullahi Ahmed An. Toward an Islamic reformation: Civil liberties, human rights, and international law. 5 ed. New York: Syracuse University Press, 1996.

Russell, Stephen T., dan Jessica N. Fish. "Mental Health in Lesbian, Gay, Bisexual, and Transgender (LGBT) Youth." Annual Review of Clinical Psychology (2016).

$\mathrm{Su}$, Dejun, Jay A. Irwin, Christopher Fisher, Athena Ramos, Megan Kelley, Diana Ariss Rogel Mendoza, dan Jason D. Coleman. “Mental Health Disparities Within the LGBT Population: A Comparison Between Transgender and Nontransgender Individuals." Transgender Health 1, no. 1 (2016): 12-20.

al-Syātịīì, Abū Isḥaq al-Muwafaqāt fì Ușūl al-Syarī'ah Juz II Beirūt: Dār al-Ma'rifah, 1997

\section{Website Sources}

https://nasional.tempo.co/read/1057953/dpr-dan-mui-sepakat-lgbt-dipidana-dalamrkuhp

https://www.liputan6.com/global/read/2963642/4-kasus-lgbt-di-indonesia-yangdisorot-dunia

https://nasional.tempo.co/read/1044655/pakar-hukum-ada-kekosongan-hukumtentang-lgbt-di-indonesia

http://www.republika.co.id/berita/jurnalisme-warga/wacana/16/01/28/o1n41d336menelisik-perjalanan-lgbt-di-indonesia

http://www.republika.co.id/berita/jurnalisme-warga/wacana/17/12/22/p1cv94396-

lgbt-konspirasi-global-acaman-keluarga-indonesia

https://nasional.sindonews.com/read/1277651/15/komunis-dan-lgbt-menjadi-

kelompok-yang-paling-tak-disukai-di-indonesia-1517218449

http://mui.or.id/wp-content/uploads/2017/02/Lesbian-Gay-Sodomi-dan-

Pencabulan.pdf 